\title{
Effects of Ginkgo biloba extracts with mirodenafil on the relaxation of corpus cavernosal smooth muscle and the potassium channel activity of corporal smooth muscle cells
}

\author{
Jung Jun Kim ${ }^{1, *}$, Deok Hyun Han, ${ }^{1, *}$, Soo Hyun Lim ${ }^{1}$, Tae Hun Kim ${ }^{1}$, Mee Ree Chae ${ }^{1}$, Kyung Jin Chung ${ }^{2}$, \\ Sung Chul Kam ${ }^{3}$, Ju-Hong Jeon ${ }^{4}$, Jong Kwan Park ${ }^{5}$ and Sung Won Lee ${ }^{1}$
}

In this study, we investigated the effects of a combination of Ginkgo biloba extracts (GBE) and phosphodiesterase type 5 (PDE-5) inhibitors on the muscular tone of the corpus cavernosum and potassium channel activity of corporal smooth muscle cells. Strips of corpus cavernosum from male New Zealand white rabbits were mounted in organ baths for isometric tension studies. After contraction with $1 \times 10^{-5} \mathrm{~mol} \mathrm{I}^{-1}$ norepinephrine, GBE $\left(0.01-1 \mathrm{mg} \mathrm{ml}^{-1}\right)$ and mirodenafil $\left(0.01-100 \mathrm{nmol} \mathrm{I}{ }^{-1}\right)$ were added together into the organ bath. In electrophysiological studies, whole-cell currents were recorded by the conventional patch-clamp technique in cultured smooth muscle cells of the human corpus cavernosum. The corpus cavernosum was relaxed in response to GBE in a dose-dependent manner (from $0.64 \% \pm 8.35 \%$ at $0.01 \mathrm{mg} \mathrm{ml}^{-1}$ to $52.28 \% \pm 11.42 \%$ at $1 \mathrm{mg} \mathrm{ml}^{-1}$ ). After pre-treatment with $0.03 \mathrm{mg} \mathrm{ml}^{-1}$ of GBE, the relaxant effects of mirodenafil were increased at all concentrations. After tetraethylammonium (TEA) $\left(1 \mathrm{mmol} \mathrm{I}^{-1}\right)$ administration, the increased effects were inhibited $(\boldsymbol{P}<0.01)$. Extracellular administration of GBE increased the whole-cell $\mathrm{K}^{+}$outward currents in a dose-dependent fashion. The increase of the outward current was inhibited by $1 \mathrm{mmol} \mathrm{I}{ }^{-1}$ TEA. These results suggest that GBE could increase the relaxant potency of mirodenafil even at a minimally effective dose. The $\mathrm{K}^{+}$flow through potassium channels might be one of the mechanisms involved in this synergistic relaxation.

Asian Journal of Andrology (2011) 13, 742-746; doi:10.1038/aja.2010.184; published online 11 April 2011

Keywords: calcium-activated potassium channels; erectile dysfunction; Ginkgo biloba; phosphodiesterase inhibitors; smooth muscles

\section{INTRODUCTION}

Ginkgo biloba extract (GBE) is derived from dried Ginkgo biloba leaves and contains $24 \%$ ginkgo flavonol glycosides and $6 \%$ terpene lactones such as ginkgolides A, B, C, J and bilobalide. Clinically, it is one of the most commonly prescribed botanical drugs. Vasorelaxative effects are the main function of GBE, and there are many clinical therapeutic applications associated with chronic vascular insufficiency, such as peripheral arterial obstructive disease, cognitive dysfunction, ${ }^{1}$ ageing damage $^{2}$ and Alzheimer's disease. ${ }^{3}$

Traditionally, GBE is believed to have positive effects on sexual function in men; therefore, it is widely used as a potential enhancer of penile erection in Korea. Penile erection is a haemodynamic event, which is coordinated with smooth muscle relaxation of the corpus cavernosum. Reduced penile vascular resistance induced by corporal smooth muscle relaxation is the most important step in penile erection. ${ }^{4}$ Although the efficacy of GBE for erectile dysfunction (ED) has been infrequently studied, recent work by Paick and Lee ${ }^{5}$ demonstrated relaxant effects of GBE on corpus cavernosal tissues in studies using organ bath models and suggested its potential use for ED in a clinical setting.

ED is a common disorder in men. ${ }^{6,7}$ The incidence of ED has increased due to the modern lifestyle associated with limited physical activity and high-calorie intake. ${ }^{8} \mathrm{ED}$ is prevalent in patients with cardiovascular comorbidities, diabetes and elevated fasting glucose levels, and is reportedly associated with future coronary risk. ${ }^{9}$ Although oral forms of phosphodiesterase type 5 (PDE-5) inhibitors have been prescribed as a first-line treatment for $\mathrm{ED}$, some men discontinue PDE-5 inhibitor usage because of the lack of effectiveness. Even after usage instructions are optimized as either an as-needed or a daily protocol, the success rate per attempts at intercourse has been reported to be less than $50 \% .^{10,11}$ Although other invasive options such as intracavernousal injections or penile prostheses are available,

${ }^{1}$ Department of Urology, Samsung Medical Center, Sungkyunkwan University School of Medicine, Seoul 135-710, Korea; ${ }^{2}$ Department of Urology, Gachon University Gil Hospital, Incheon 405-760, Korea; ${ }^{3}$ Department of Urology, Gyeongsang National University College of Medicine, Gyeongsangnam-do 660-702, Korea; ${ }^{4}$ Department of Physiology and Biophysics, Seoul National University College of Medicine, Seoul 110-799, Korea and ${ }^{5}$ Department of Urology, Medical School, Chonbuk National University, and Institute for Medical Sciences, Chonbuk National University, and Research Institute and Clinical Trial Center of Medical Device of Chonbuk National University Hospital, Jeonju-si 561-712, Korea

* These two authors contributed equally to this work

Correspondence: Dr SW Lee (drswlee@skku.edu)

Received: 19 September 2010; Revised: 7 November 2010; Accepted: 18 December 2010; Published online: 11 April 2011 
they are less acceptable for most men due to their invasiveness and inconvenience. ${ }^{12}$ Therefore, many men diagnosed with ED could benefit from additional treatment options with non-invasive approaches.

Considering the possible efficacy of GBE for relaxing corpus cavernosal smooth muscle, concurrent administration with a PDE-5 inhibitor might potentiate the effects of the PDE-5 inhibitor. In this study, we evaluated the potential benefit of the combination of GBE and mirodenafil, a PDE-5 inhibitor, on the relaxation of the corpus cavernosum in an ex vitro tissue model. In addition, we performed electrophysiological studies to investigate the mechanism of action of GBE on the potassium channel in human corporal smooth muscle cells (SMCs).

\section{MATERIALS AND METHODS}

\section{Tissue relaxation measurements}

This experiment was reviewed and approved by the Institutional Animal Care and Use Committee of Samsung Biomedical Research Institute. The Samsung Biomedical Research Institute is an International Association for Assessment and Accreditation of Laboratory Animal Care accredited facility and abides by the Institute of Laboratory Animal Resources guidelines. Penile erectile tissue was obtained from male rabbits (22-26 weeks old; 3-4 kg body weight). The rabbits were killed by transvenous embolisation. The entire penis was surgically removed and rapidly placed in a modified Krebs solution $\left(\mathrm{NaCl} 114.0, \mathrm{NaHCO}_{3} 25.0, \mathrm{CaCl}_{2} 2.5, \mathrm{KCl}\right.$ 4.7, $\mathrm{MgSO}$ $1.2, \mathrm{KH}_{2} \mathrm{PO}_{4} 1.2$, glucose 11.7 and ascorbic acid 1.0; all concentrations in $\mathrm{mmol}^{-1}$ ) under conditions of $95 \% \mathrm{O}_{2}$ and $5 \% \mathrm{CO}_{2}$.

The corpus cavernosum was carefully dissected by removing surrounding adipose and muscular tissues and the tunica albuginea under a microscope. The corpus cavernosum was prepared as two longitudinal strips $(0.6-0.8 \mathrm{~cm})$ and mounted under $1 \mathrm{~g}$ of resting tension in a 5-ml jacketed organ bath containing modified Krebs solution (composition as described above) bubbled with $95 \% \mathrm{O}_{2}$ and $5 \% \mathrm{CO}_{2}$, and maintained at $37{ }^{\circ} \mathrm{C}$. An equilibration period of $1 \mathrm{~h}$ was used for all tissues in this study. During this period, the tissues were washed with fresh Krebs solution, and the baseline tension was readjusted to $1 \mathrm{~g}$. Tissue responses were measured using isometric strain gauges connected to a polygraph and an electronic data acquisition system run on a personal computer. Corpus cavernosal tissue was precontracted with $1 \times 10^{-5} \mathrm{~mol} \mathrm{l}^{-1}$ of norepinephrine (NE). After a stable plateau of contractions was obtained, the relaxant compounds were added.

First, to determine the dose of GBE to use in combination with mirodenafil, GBE was cumulatively added from 0.01 to $1 \mathrm{mg} \mathrm{ml}^{-1}$, and the relaxation was measured. Second, mirodenafil was cumulatively added from 0.01 to $100 \mathrm{nmol}^{-1}$, and the relaxation was measured. After pre-treatment with $0.03 \mathrm{mg} \mathrm{ml}^{-1}$ of GBE, mirodenafil was cumulatively added. Finally, the whole organ bath procedure was repeated after administration of tetraethylammonium (TEA), a selective blocker of large-conductance calcium-activated potassium channels ( $\mathrm{BK}_{\mathrm{Ca}}$ channels).

\section{Explant cell cultures and electrophysiological recordings}

This experiment was approved by the Institutional Review Board (IRB) of Samsung Medical Center (Seoul, Korea). All participants granted written informed consent. Human erectile tissue was obtained from the corpus cavernosum of patients undergoing surgery for implantation of penile prostheses or penectomy for penile cancer. Homogeneous explant cell cultures of human corporal SMCs were prepared as previously described. ${ }^{13}$ SMCs were cultured with
Dulbecco's medium (Gibco Invitrogen, Carlsbad, CA, USA) supplemented with $10 \%$ foetal bovine serum, $1 \%$ penicillin/streptomycin and $2 \mathrm{mmol}^{-1} \mathrm{~L}$-glutamine at $37^{\circ} \mathrm{C}$ in a humidified incubator with $5 \% \mathrm{CO}_{2}$ atmosphere. These cultures were morphologically homogeneous, and furthermore, we did not observe cobblestone morphologies characteristic of endothelial cells or the flattened and spread-out shapes characteristic of fibroblasts. Cellular homogeneity was further verified by the presence of smooth muscle specific $\alpha$-actin immunoreactivity. All experiments were performed within four culture passages, and during this time, changes were not observed in any experimentally relevant pharmacological and molecular properties, including cyclic adenosine monophosphate (cAMP) formation, calcium mobilisation and expression or function of the gap junction protein connexin43. For the electrophysiological studies, the confluent cells were trypsinized $\left(0.05 \%(\mathrm{w} / \mathrm{v})\right.$ trypsin and $5 \mathrm{mmoll}^{-1}$ EDTA) and replated onto glass coverslips in $35-\mathrm{mm}$ culture dishes. The experiments were conducted within $3 \mathrm{~h}$ of the cells attaching to the glass coverslips.

The conventional whole-cell patch-clamp method was used to measure the membrane currents under voltage clamp conditions. The cells on glass coverslips were placed into a small chamber $(0.6 \mathrm{ml})$ on the stage of an inverted microscope (TMD Diaphot; Nikon, Tokyo, Japan). Membrane currents in the SMCs were recorded using a patch-clamp amplifier (Axopatch-lD; Axon Instruments, Foster City, CA, USA). The patch electrodes were made from borosilicate glass capillary tubing (World Precision Instruments, Sarasota, FL, USA) and had resistances of 2.5-5 M $\Omega$. Series resistance (about 6$10 \mathrm{M} \Omega$ ) and capacitative currents were not compensated for because the cell size and measured currents were relatively small. The membrane capacitance was determined from the current amplitude elicited in response to hyperpolarizing voltage ramp pulses from a holding potential of 0 to $-5 \mathrm{mV}$ (duration $25 \mathrm{~ms}$ at $0.2 \mathrm{~V} \mathrm{~s}^{-1}$ ); there was no interference due to any time-dependent ionic currents throughout the duration of this experiment. The average cell capacitance was $35.3 \pm 2.6 \mathrm{pF}(n=44)$. pCLAMP software v.9.2 and Digidata-1322A (both from Axon Instruments Inc.) were used for data acquisition and the application of command pulses. Membrane currents were measured during ramp and filtered at $5 \mathrm{kHz}(-3 \mathrm{~dB}$ frequency). Current signals were filtered at $5 \mathrm{kHz}$, digitized and analysed on a personal computer using the pCLAMP software (version 9.2; Axon Instruments) and Origin v.7.0 (Microcal Software Inc., Northampton, MA, USA). The standard bath solution contained the following components ( $\mathrm{mmoll}^{-1}$ ): $134 \mathrm{NaCl}, 6 \mathrm{KCl}, 1 \mathrm{MgCl}_{2}, 2 \mathrm{CaCl}_{2}, 5$ glucose and 10 HEPES, pH 7.4 with $\mathrm{NaOH}$. The pipette solution contained the following (in m mol $1^{-1}$ ): $140 \mathrm{KCl}, 10$ HEPES, $2 \mathrm{~K}_{2} \mathrm{ATP}, 3.3 \mathrm{CaCl}_{2}, 2$ $\mathrm{MgCl}_{2}$, 5 ethyleneglycol-bis-[2-aminoethyl ether]-N, $\mathrm{N}^{\prime}$-tetraacetic acid and 1 GTP, and the $\mathrm{pH}$ was adjusted to 7.2 with $\mathrm{KOH}$.

\section{Drugs and chemicals}

All drugs and chemicals were purchased from Sigma (St Louis, MO, USA), with the exception of mirodenafil and GBE. Mirodenafil (a PDE-5 inhibitor) and GBE were provided by SK Chemical (Seoul, Korea). GBE was prepared in dimethylsulphoxide and freshly diluted in bath solution immediately before use. The final concentration of dimethylsulphoxide did not exceed $0.1 \%$. All other drugs were prepared in distilled water.

\section{Data analysis}

The relaxant effects of drugs on corpus cavernosal tissues were expressed as the per cent inhibition of the contractions that were 
induced by phenylephrine before adding relaxant drugs. To compare the relaxation effect, the Wilcoxon rank-sum test was performed. Descriptive statistics were used for electrophysiological recordings. SPSS 17.0K software (SPSS Inc., Chicago, IL, USA) was used, and statistical significance was accepted at $P<0.05$.

\section{RESULTS}

\section{Relaxant effect of GBE on corporal tissue}

The corpus cavernosum was relaxed in response to GBE in a dosedependent manner. The cumulative relaxation effects of GBE were $0.64 \% \pm 8.35 \%$ at $0.01 \mathrm{mg} \mathrm{ml}^{-1}, 8.79 \% \pm 9.26 \%$ at $0.03 \mathrm{mg} \mathrm{ml}^{-1}$, $20.52 \% \pm 9.26 \%$ at $0.1 \mathrm{mg} \mathrm{ml}^{-1}, 32.72 \% \pm 8.53 \%$ at $0.3 \mathrm{mg} \mathrm{ml}^{-1}$ and $52.28 \% \pm 11.42 \%$ at $1 \mathrm{mg} \mathrm{ml}^{-1}$. The relaxation potency was not significant at the dose of $0.01 \mathrm{mg} \mathrm{ml}^{-1}(P=0.786)$; however, GBE did begin to demonstrate significant relaxant effects on the corpus cavernosum at $0.03 \mathrm{mg} \mathrm{ml}^{-1}(P=0.017$; Figure 1$)$. Based on these data, we decided to use $0.03 \mathrm{mg} \mathrm{ml}^{-1}$ of GBE in consecutive experiments measuring the additional relaxant effects of GBE on the corpus cavernosum with mirodenafil.

\section{Relaxant effect of mirodenafil on corporal tissue}

The corpus cavernosum was relaxed in response to mirodenafil in a dose-dependent manner. The cumulative relaxation effects of mirodenafil were $10.53 \% \pm 7.94 \%$ at $0.1 \mathrm{nmol} \mathrm{l}^{-1}, 18.95 \% \pm 8.50 \%$ at $1 \mathrm{nmol} \mathrm{l}^{-1}, 27.36 \% \pm 11.28 \%$ at $10 \mathrm{nmol}^{-1}$ and $46.33 \% \pm 12.12 \%$ at $100 \mathrm{nmol}^{-1}$. When pre-treated with $0.03 \mathrm{mg} \mathrm{ml}^{-1}$ of GBE, relaxation effects of mirodenafil were enhanced. The per cent relaxations of mirodenafil combined with GBE were $12.21 \pm 6.05 \%$ at $0.1 \mathrm{nmol} \mathrm{l}^{-1}$, $20.53 \pm 5.89 \%$ at $1 \mathrm{nmol} \mathrm{l}^{-1}, 33.51 \% \pm 13.53 \%$ at $10 \mathrm{nmol} \mathrm{l}^{-1}$ and $60.39 \% \pm 13.82 \%$ at $100 \mathrm{nmol}^{-1}(n=8$; Figure 2).

After administration of the TEA, the per cent relaxation by the mirodenafil and GBE was measured. Following precontraction by $\mathrm{NE}\left(1 \times 10^{-5} \mathrm{~mol}^{-1}\right), 1 \mathrm{mmol} \mathrm{1}^{-1}$ of TEA was administered prior to adding GBE to the organ bath. The relaxation effects of different doses of mirodenafil and $0.3 \mathrm{mg} \mathrm{ml}^{-1}$ of GBE after administration of TEA $\left(1 \mathrm{mmol} \mathrm{l}^{-1}\right)$ were $7.71 \% \pm 2.73 \%$ at $0.1 \mathrm{nmol} \mathrm{l}^{-1}$, $11.20 \% \pm 3.47 \%$ at $1 \mathrm{nmol} 1^{-1}, 15.99 \% \pm 5.39 \%$ at $10 \mathrm{nmol} 1^{-1}$ and $22.20 \% \pm 7.78 \%$ at $100 \mathrm{nmol} 1^{-1}$. The increasing relaxation effects caused by mirodenafil and GBE were inhibited by TEA administration $(n=8, P<0.01$; Figure 3).

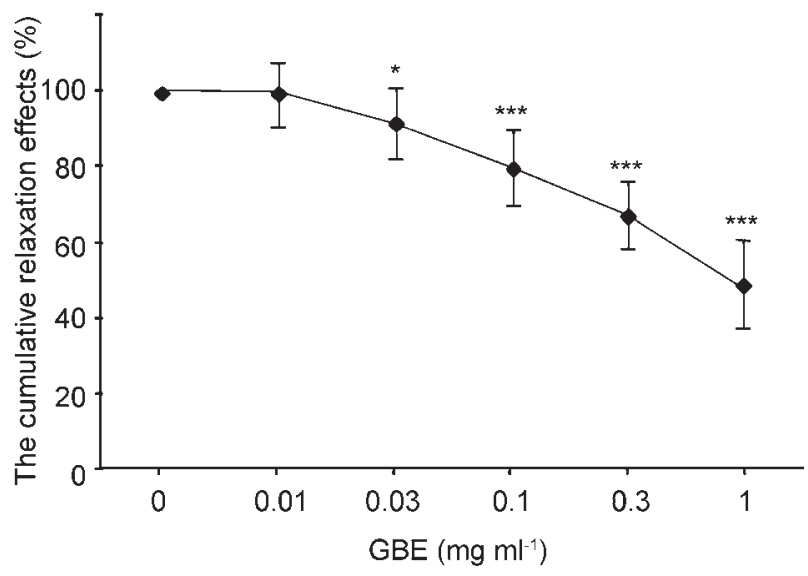

Figure 1 Relaxation effects of Ginkgo biloba extracts (GBE) on $10^{-5} \mathrm{~mol} \mathrm{I}^{-1}$ norepinephrine (NE)-induced contractions of rabbit cavernosal strips $(n=12)$. $* P<0.05, * * * P<0.0001$, compared with the control.

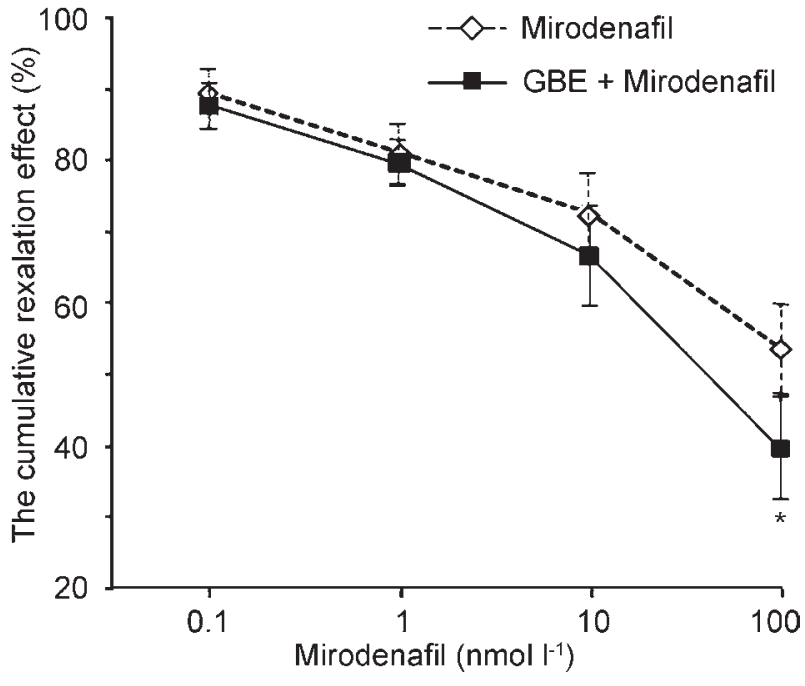

Figure 2 Relaxation effects of mirodenafil on $10^{-5}$ mol I-1 norepinephrine (NE)induced contractions of rabbit cavernosal strips in the absence (round circle) or presence (square) of $0.03 \mathrm{mg} \mathrm{ml}^{-1}$ Ginkgo biloba extracts (GBE) $(n=8)$. $* P<0.05$, compared with the control.

\section{Activation of $\mathrm{BK}_{\mathrm{Ca}}$ whole-cell currents by $\mathrm{GBE}$}

The effects of GBE on potassium currents in human corporal SMCs were investigated using the patch-clamp recording technique. The membrane currents were elicited by a $500-\mathrm{ms}$ depolarizing pulse from -100 to $60 \mathrm{mV}$. The extracellular administration of GBE increased the whole cell $\mathrm{K}^{+}$outward currents (Figure 4). The response magnitude was dose-dependent at $+60 \mathrm{mV}$ (control: $8.7 \pm 1.8 \mathrm{pA} / \mathrm{pF}, n=18$; $0.01 \mathrm{mg}$ GBE: $16.2 \pm 3.1 \mathrm{pA} / \mathrm{pF}, n=7 ; 0.03 \mathrm{mg}$ GBE: $44.5 \pm 9.0 \mathrm{pA} /$ $\mathrm{pF}, n=7 ; 0.1 \mathrm{mg}$ GBE: $49.9 \pm 9.0 \mathrm{pA} / \mathrm{pF}, n=8 ; 0.3 \mathrm{mg}: \mathrm{GBE}$ $52.9 \pm 5.0 \mathrm{pA} / \mathrm{pF}, n=12)$. The increase of outward current was inhibited by $1 \mathrm{mmol}^{-1}$ of TEA, a selective blocker of $\mathrm{BK}_{\mathrm{Ca}}$ channels at this

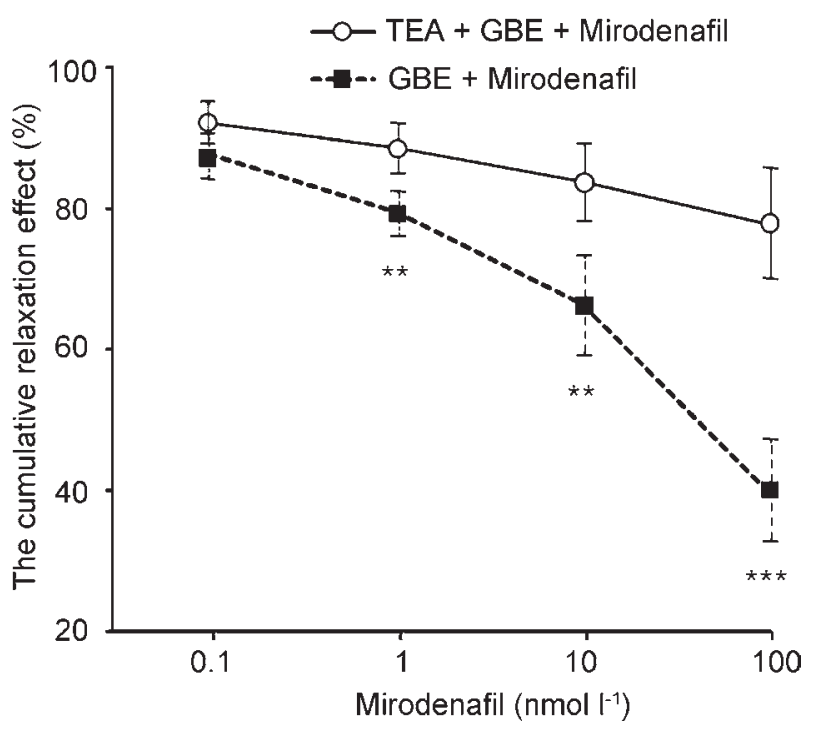

Figure 3 Relaxation effects of mirodenafil on $10^{-5} \mathrm{~mol} \mathrm{I}^{-1}$ norepinephrine (NE)induced contractions of rabbit cavernosal strips with pretreatment of $0.03 \mathrm{mg}$ $\mathrm{ml}^{-1}$ Ginkgo biloba extracts (GBE) in the absence (round circle) or presence (square) of $1 \mathrm{mmol} \mathrm{I}^{-1}$ tetraethylammonium (TEA) $(n=8)$. *** $P<0.01$, $* * * P<0.0001$, compared with the control. 
a

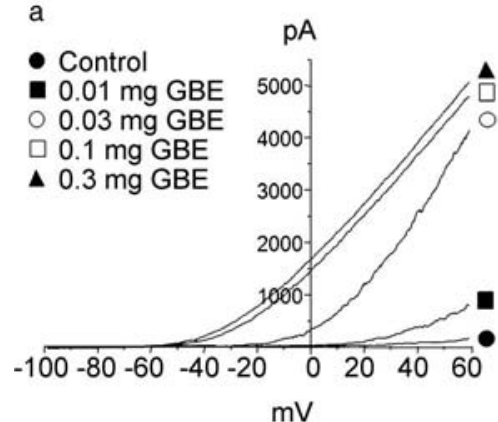

b

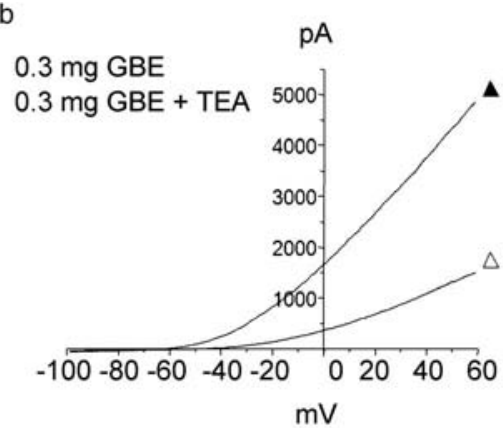

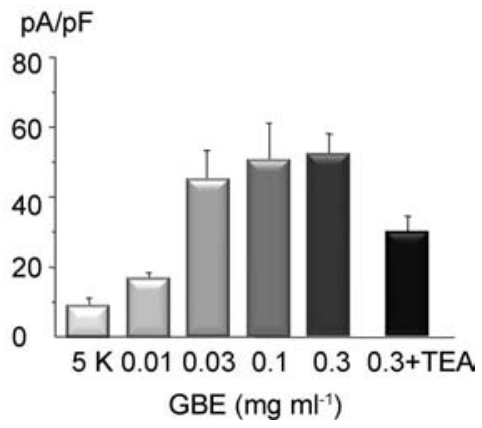

Figure 4 Effect of Ginkgo biloba extracts (GBE) on the BK $\mathrm{Ca}$ channel whole-cell currents in human corporal smooth muscle cells. (a) Current-voltage relationships obtained using a 500-ms ramp pulse from -100 to $+60 \mathrm{mV}$. Membrane currents were recorded before and 5 min after administration of GBE. (b) GBE-stimulated currents were inhibited by $1 \mathrm{mmol} \mathrm{I}{ }^{-1}$ tetraethylammonium (TEA), a BK $\mathrm{Ca}$ channel selective inhibitor. (c) Summary of the means \pm s.e. of peak whole-cell currents at $+60 \mathrm{mV}(n=12)$

concentration (Figure $4 \mathrm{~b}$ ). A summary of the stimulatory effects of GBE followed by administration of TEA is presented in Figure 4c.

\section{DISCUSSION}

PDE-5 inhibitors are commonly prescribed as first-line treatment for $\mathrm{ED}$; however, a significant proportion of men do not respond to PDE5 inhibitor treatment. ${ }^{14}$ The mechanism of action of PDE-5 inhibitors is through the inhibition of intracellular cyclic guanosine monophosphate (cGMP) degradation, but the underlying mechanism associated with non-responsiveness is unclear. Nevertheless, there are a considerable number of men who are PDE- 5 non-responders and seek additional non-invasive treatment options. ${ }^{12}$ The combination of a PDE-5 inhibitor with other drugs might be an alternative option, if efficacy and safety can be demonstrated. If a drug combination could improve the potency of the PDE-5 inhibitor, this population of men may respond to the PDE-5 inhibitor. Furthermore, some PDE-5 inhibitor responders could potentially reduce their PDE-5 inhibitor dose with the combination treatment.

Some studies have shown that severe vascular lesions and atrophy of SMCs were observed in sildenafil non-responders; therefore, drugs that maintain the structure and function of the penile vasculature, by preventing endothelial and SMC dysfunction and damage, may improve the response to PDE-5 inhibitors. ${ }^{12}$ Clinically, GBE has been commonly prescribed to protect from vascular insufficiencies and peripheral vascular diseases. ${ }^{15}$ The main action of GBE is suggested to be the relaxation of vascular smooth muscles and the enhancement of endothelial functions; there are many clinical therapeutic applications of GBE for conditions associated with chronic vascular insufficiency. ${ }^{1-3}$ In the current experiment, GBE induced relaxation of the corpus cavernosum in a dose-dependent manner. The relaxant potency of GBE itself was demonstrated to be more than $50 \%$ at a dose of $1 \mathrm{mg} \mathrm{ml}^{-1}$ and about $9 \%$ at a dose of $0.03 \mathrm{mg} \mathrm{ml}^{-1}$. There are several potential mechanisms by which GBE plays a role in the relaxation of corporal smooth muscles. As Ginkgo biloba dimeric flavonoids were shown to inhibit cAMP-specific PDE activity in a rat aorta model and have also been shown to inhibit human cGMP-specific PDE-5, inhibition of PDE is one possible mechanism that explains the relaxation activity of the corpus cavernosum by GBE. ${ }^{16,17}$ GBE maintains ATP content by protecting mitochondrial respiration and preserving oxidative phosphorylation, and it also exerts arterial and venous vasoregulator effects involving the release of endothelial factors. ${ }^{18}$ In addition, GBE regulates the ionic balance in damaged cells and exerts specific and potent platelet-activating factor antagonist activity. ${ }^{19}$

The endothelium-dependent vasorelaxation of GBE has previously been studied with regard to biochemical and pharmacological characteristics. ${ }^{20}$ Various mechanisms including NO release, ${ }^{21}$ activation of the $\mathrm{K}^{+}$channel, $^{22}$ and prostacyclin release ${ }^{23}$ have been suggested to be involved in the smooth muscle relaxation by GBE. In the corporal smooth muscle, $\mathrm{K}^{+}$channels perform a key role in determining smooth muscle tone. In human corporal smooth muscle cells that express ATP-sensitive potassium channels, the $\mathrm{BK}_{\mathrm{Ca}}$ channel is thought to be the most important for modulating muscle tone. ${ }^{24,25}$ Due to the large conductance and high density of expression, $\mathrm{BK}_{\mathrm{Ca}}$ channels help set and maintain the resting membrane potential of human corporal smooth muscle. ${ }^{26}$ In an electrophysiological study using porcine aorta, it was demonstrated that the application of GBE to the intracellular surface of excised inside-out patches activated $\mathrm{K}^{+}$channels in a concentration-dependent manner in the concentration range of $1-100 \mu \mathrm{g} \mathrm{ml}^{-1} .^{23}$ The authors suggested that GBE increased nitric oxide synthase (NOS) activity in a manner dependent upon the activity of $\mathrm{BK}_{\mathrm{Ca}}$ channels and that $\mathrm{GBE}$ may regulate NO release by changing the cell membrane potential in vascular endothelial cells. However, there are controversies for the effects of $\mathrm{GBE}$ on the $\mathrm{BK}_{\mathrm{Ca}}$ channel of smooth muscles. In a previous study, the relaxation effects of GBE were assessed after a 30-min pre-treatment with TEA. Authors demonstrated that TEA did not reduce the GBE-induced vasorelaxation in a rat aorta model at any concentration of GBE $\left(0.03-3 \mathrm{mg} \mathrm{ml}^{-1}\right){ }^{27}$ Our data, however, show that GBE increased the probability of opening the $\mathrm{BK}_{\mathrm{Ca}}$ channel in the cell-attached patch, consistent with the increased whole-cell current in the human corpus cavernosal cells. The increased $\mathrm{K}^{+}$flow caused by GBE was effectively inhibited by TEA. Additionally, TEA showed significant inhibitory effects on the relaxation potency of GBE combined with mirodenafil in the organ bath model. Based on these results, the activation of potassium channels, mainly $\mathrm{BK}_{\mathrm{Ca}}$ channels, appears to have an important role in the GBEinduced relaxation of the corpus cavernosum.

GBE is usually prescribed for daily use, whereas PDE-5 inhibitors are prescribed for use as necessary. In the present study, we added mirodenafil after pre-administration of GBE to duplicate the clinical situation. To our knowledge, there have been no other studies evaluating whether GBE could show additional relaxation effects on the corpus cavernosum when combined with PDE-5 inhibitors. In our current experiments, GBE increased the relaxant potency of PDE-5 inhibitors on the corpus cavernosum even with the minimally 
significant dose (Figure 1). Additional relaxation effects were demonstrated to increase in a dose-dependent manner, but the statistics were significant only at the maximal dose (Figure 2). Because the average maximum plasma concentration $\left(C_{\max }\right)$ of mirodenafil was shown to be $354.9 \mathrm{ng} \mathrm{ml}^{-1}(587.0 \mathrm{nM}){ }^{28}$ experimental doses of mirodenafil used in this study $(0.1-100 \mathrm{nM})$ seem to be relevant to actual therapeutic ranges. These results could provide evidence to support additional in vivo studies and clinical trials using the combination therapy of GBE and PDE-5 inhibitors to treat erectile dysfunction, especially in PDE-5 inhibitor non-responders.

\section{CONCLUSION}

GBE induced the relaxation of the corpus cavernosum in a dosedependent manner and also effectively increased the relaxant potency of mirodenafil in rabbit corpus cavernosal tissues even at the minimally effective dose. The $\mathrm{K}^{+}$flow through potassium channels, mainly by $\mathrm{BK}_{\mathrm{Ca}}$ channels, might be one mechanism involved in the synergistic relaxation observed. Our results may be used to support further in vivo experiments or clinical investigations on the combination therapy of GBE with PDE-5 inhibitors for the treatment of ED.

\section{AUTHOR CONTRIBUTIONS}

JJK and DHH conceived of the study, and participated in its design and drafted the manuscript. SHL and THK carried out tissue relaxation measurements by organ bath and helped to draft the manuscript. MRC, KJC and SCK participated in the design of the study and performed explant cell cultures and electrophysiological studies, and performed the statistical analysis. JHJ and JKP conceived of the study, and participated in the design of the study and involved in revising the manuscript critically for important intellectual content. SWL conceived of the study, and participated in its design and coordination and helped to draft the manuscript and involved in revising the manuscript critically. All authors read and approved the final manuscript.

\section{COMPETING FINANCIAL INTERESTS}

The authors have nothing to disclose.

\section{ACKNOWLEDGMENTS}

This study was supported by a grant from the Korea Healthcare Technology R\&D Project, Ministry for Health, Welfare and Family Affairs, Korea (A090583).

1 Kennedy DO, Scholey AB, Wesnes KA. The dose-dependent cognitive effects of acute administration of Ginkgo biloba to healthy young volunteers. Psychopharmacology (Berl) 2000; 151: 416-23.

2 Diamond BJ, Shiflett SC, Feiwel N, Matheis RJ, Noskin 0 et al. Ginkgo biloba extract: mechanisms and clinical indications. Arch Phys Med Rehabil 2000; 81: 668-78.
3 Le Bars PL, Katz MM, Berman N, Itil TM, Freedman AM et al. A placebo-controlled, double-blind, randomized trial of an extract of Ginkgo biloba for dementia. North American EGb Study Group. JAMA 1997; 278: 1327-32.

$4 \mathrm{Han}$ DH, Chae MR, So I, Park JK, Lee SW. The effects of dopamine receptor agonists on $\mathrm{BK}_{\mathrm{Ca}}$ channels and signal transduction mechanism in corpus cavernosal smooth muscle cells. Int J Impot Res 2008; 20: 53-9.

5 Paick JS, Lee JH. An experimental study of the effect of ginkgo biloba extract on the human and rabbit corpus cavernosum tissue. J Urol 1996; 156: 1876-80.

6 Feldman HA, Goldstein I, Hatzichristou DG, Krane RJ, McKinlay JB. Impotence and its medical and psychosocial correlates: results of the Massachusetts Male Aging Study. J Urol 1994; 151: 54-61.

7 Kubin M, Wagner G, Fugl-Meyer AR. Epidemiology of erectile dysfunction. Int J Impot Res 2003; 15: 63-71.

8 Bacon CG, Mittleman MA, Kawachi I, Giovannucci E, Glasser DB et al. Sexual function in men older than 50 years of age: results from the health professionals follow-up study. Ann Intern Med 2003; 139: 161-8.

9 Grover SA, Lowensteyn I, Kaouache M, Marchand S, Coupal L et al. The prevalence of erectile dysfunction in the primary care setting: importance of risk factors for diabetes and vascular disease. Arch Intern Med 2006; 166: 213-9.

10 Atiemo HO, Szostak MJ, Sklar GN. Salvage of sildenafil failures referred from primary care physicians. J Urol 2003; 170: 2356-8.

11 Hatzimouratidis K, Moysidis K, Bekos A, Tsimtsiou Z, loannidis E et al. Treatment strategy for "non-responders" to tadalafil and vardenafil: a real-life study. Eur Urol 2006; 50: 126-32; discussion 132-3.

12 Gholamine B, Shafiei M, Motevallian M, Mahmoudian M. Effects of pioglitazone on erectile dysfunction in sildenafil poor-responders: a randomized, controlled study. J Pharm Pharm Sci 2008; 11: 22-31.

13 Wespes E, Rammal A, Garbar C. Sildenafil non-responders: haemodynamic and morphometric studies. Eur Urol 2005; 48: 136-9; discussion 139.

14 Souverein PC, Egberts AC, Meuleman EJ, Urquhart J, Leufkens HG. Incidence and determinants of sildenafil (dis)continuation: the Dutch cohort of sildenafil users. Int J Impot Res 2002; 14: 259-65.

15 Kubota Y, Tanaka N, Umegaki K, Takenaka H, Mizuno H et al. Ginkgo biloba extractinduced relaxation of rat aorta is associated with increase in endothelial intracellular calcium level. Life Sci 2001; 69: 2327-36.

16 Dell'Agli M, Galli GV, Bosisio E. Inhibition of cGMP-phosphodiesterase-5 by biflavones of Ginkgo biloba. Planta Med 2006; 72: 468-70.

17 Saponara R, Bosisio E. Inhibition of cAMP-phosphodiesterase by biflavones of Ginkgo biloba in rat adipose tissue. J Nat Prod 1998; 61: 1386-7.

18 Clostre F. Ginkgo biloba extract (EGb 761). State of knowledge in the dawn of the year 2000. Ann Pharm Fr 1999; 57 (Suppl 1): 1S8-88. French.

19 Braquet $P$, Touqui L, Shen TY, Vargaftig BB. Perspectives in platelet-activating factor research. Pharmacol Rev 1987; 39: 97-145.

20 Delaflotte S, Auguet M, DeFeudis FV, Baranes J, Clostre F et al. Endotheliumdependent relaxations of rabbit isolated aorta produced by carbachol and by Ginkgo biloba extract. Biomed Biochim Acta 1984; 43: S212-6.

21 Chen X, Salwinski S, Lee TJ. Extracts of Ginkgo biloba and ginsenosides exert cerebral vasorelaxation via a nitric oxide pathway. Clin Exp Pharmacol Physiol 1997; 24: 958-9.

22 Li Z, Nakaya Y, Niwa Y, Chen X. K $\mathrm{Ca}_{\text {c }}$ channel-opening activity of Ginkgo Biloba extracts and ginsenosides in cultured endothelial cells. Clin Exp Pharmacol Physiol 2001; 28: 441-5.

23 Chatterjee SS. Effects of Ginkgo biloba extract on cerebral metabolic processes. In: Agnoli A, Rapin JR, Scapagnini V, Weitbrecht WV, editors. Effects of Ginkgo Biloba Extract on Organic Cerebral Impairment. London: John Libbery; 1985. pp5-14.

24 Christ GJ, Spray DC, Brink PR. Characterization of $\mathrm{K}$ currents in cultured human corporal smooth muscle cells. J Androl 1993; 14: 319-28.

25 Fan SF, Brink PR, Melman A, Christ GJ. An analysis of the Maxi- $\mathrm{K}^{+}\left(\mathrm{K}_{\mathrm{Ca}}\right)$ channel in cultured human corporal smooth muscle cells. J Urol 1995; 153: 818-25.

26 Archer SL. Potassium channels and erectile dysfunction. Vascul Pharmacol2002; 38 : 61-71.

27 Nishida S, Satoh H. Mechanisms for the vasodilations induced by Ginkgo biloba extract and its main constituent, bilobalide, in rat aorta. Life Sci 2003; 72: 2659-67.

28 Shin BS, Hu SK, Kim J, Oh JG, Youn WN et al. Development of LC/MS/MS assay for the determination of 5-ethyl-2-\{5-[4-(2-hydroxyethyl)piperazine-1-sulfonyl]-2-propoxy phenyl\}-7-propyl-3,5-dihydropyrrolo[3,2-d]pyrimidin-4-one (SK3530) in human plasma: application to a clinical pharmacokinetic study. J Pharm Biomed Anal 2007; 45: 176-84. 